\title{
Effect of Organic Amendments on Soilborne and Foliar Diseases in Field-Grown Snap Bean and Cucumber
}

\author{
A. G. Stone, Department of Horticulture, Oregon State University, Corvallis 97331; G. E. Vallad, Department of \\ Plant Pathology, University of Wisconsin, Madison 53706; L. R. Cooperband and D. Rotenberg, Department of \\ Soil Science, University of Wisconsin, Madison; H. M. Darby, Department of Horticulture, Oregon State Univer- \\ sity, Corvallis; and R. V. James, W. R. Stevenson, and R. M. Goodman, Department of Plant Pathology, Univer- \\ sity of Wisconsin, Madison
}

\begin{abstract}
Stone, A. G., Vallad, G. E., Cooperband, L. R., Rotenberg, D., Darby, H. M., James, R. V., Stevenson, W. R., and Goodman, R. M. 2003. Effect of organic amendments on soilborne and foliar diseases in field-grown snap bean and cucumber. Plant Dis. 87:1037-1042.

Several paper mills in Wisconsin have programs for spreading paper mill residuals (PMR) on land. A growing number of vegetable farmers recognize the agronomic benefits of PMR applications, but there have been no investigations on the use of PMR for control of vegetable crop diseases. Our objective was to determine the effect of PMR amendments on soilborne and foliar diseases of cucumber and snap bean grown on a sandy soil. Raw PMR, PMR composted without bulking agent (PMRC), or PMR composted with bark (PMRBC) were applied annually in a 3 -year rotation of potato, snap bean, and pickling cucumber. Several naturally occurring diseases were evaluated in the field, along with in situ field bioassays. All amendments suppressed cucumber damping-off and Pythium blight and foliar brown spot of snap bean. Both composts reduced the incidence of angular leaf spot in cucumber. In a separate field experiment planted with snap bean for two consecutive years, all amendments reduced common root rot severity in the second year. In a greenhouse experiment, the high rate of PMRBC suppressed anthracnose of snap bean. These results suggest that the application of raw and composted PMR to sandy soils has the potential to control several soilborne and foliar diseases.
\end{abstract}

Additional keywords: Aphanomyces euteiches, biological control, Colletotrichum lindemuthianum, Pseudomonas syringae pv. lachrymans, P. syringae pv. syringae, Pythium spp., suppressive soils

Farmers and agricultural scientists have long understood that organic amendments applied to field soils improve soil functions such as infiltration, water holding capacity, nutrient retention and release, and resistance to wind and water erosion (2). There is also evidence that organic amendments applied to field soils can suppress soilborne diseases $(3,8,17,21,30)$. Disease suppression includes the reduction of both disease incidence and severity. Organic matter inputs, from plant residues to composted organic wastes, significantly reduced the severity of root rots caused by a variety of fungal plant pathogens in natural

Corresponding author: A. G. Stone

E-mail: stonea@science.oregonstate.edu

This research was funded by the University of Wisconsin CALS Research Division (Hatch Funds), the Wisconsin Potato and Vegetable Growers' Association, the Wisconsin PURR (Pesticide Use Risk Reduction) program, and a Postdoctoral Fellowship from the USDACSREES-NRI Biologically Based Pest Management Program.

Accepted for publication 5 March 2003

Publication no. D-2003-0630-01R

(C) 2003 The American Phytopathological Society systems $(19,25)$ and field agricultural systems $(3,8,17,21,30)$.

Organic matter (OM)-mediated suppression of soilborne diseases in field soils caused by pathogenic species of Pythium and Phytophthora has been reported for a variety of plant species and organic substrates $(17,19,20,23)$. Although there are fewer studies on OM-mediated suppression of root rots caused by Aphanomyces spp., both decomposing plant residues and organic wastes reduced root rot severity in pea and sugar beet $(21,22,26,34)$.

The mechanisms involved in OM-mediated suppression of root rots in compostamended and peat-based container systems have been researched and reviewed $(12,13)$. In general, most minimally decomposed organic materials suppress root rots caused by pathogenic species of $P y$ thium and Phytophthora. The duration of suppression varies with substrate and is related to the availability of labile (easily degradable) organic matter in the substrate, which potentially supports the activities of a variety of organisms engaged in biological control $(12,29)$. Competition for carbon $(5,9)$ and for iron (4), antibiotic production (11), parasitism (6), and systemic acquired resistance (36) all may contribute to suppression of soilborne plant pathogens in field soils or container mixes. This is considered "general suppression", because it is generated through the combined activities of many species of soil organisms (7).

There are fewer studies on the influence of organic amendments on foliar diseases. Soil and rhizosphere microorganisms can induce resistance to foliar diseases in plants grown in containers $(18,24)$ and in the field (33). Zhang et al. $(36,37)$ demonstrated that a composted pine bark container mix suppressed Pythium root rot and foliar anthracnose on cucumber, whereas a dark peat container mix suppressed neither (36).

Studies using a container system showed that OM-mediated suppression of soilborne diseases was fairly common, but less than $10 \%$ of composts tested in container mixes suppressed foliar diseases (16). Foliar disease suppression may be generated less frequently than root rot suppression in container mixes because foliar disease suppression requires the presence of specific organisms that are relatively infrequent colonizers of organic wastes (16).

There are few studies documenting the potential for OM amendments to suppress foliar diseases in the field. We found only two reports: the suppression of bacterial spot of tomato, caused by Xanthomonas campestris pv. vesicatoria, in a compostamended field soil (1), and the suppression of bacterial spot of radish (causal agent, $X$. campestris pv. armoraciae) using an in situ bioassay in a long-term no-till field trial (35). Low-input and organic systems typically exhibit reduced root disease incidence relative to conventional farming systems, but there is no clear trend in foliar disease incidence in comparative farming systems trials (32).

In summary, many types of organic materials suppress soilborne diseases caused by pathogens such as Pythium and Phytophthora spp. in container systems, and suppressiveness typically is related to substrate availability and microbial activity. In contrast, OM-mediated foliar disease suppression appears to be less easily generated, and soil or substrate properties related to foliar disease suppression have not been identified.

This research is part of a long-term, multidisciplinary effort to study the broad effects of raw or composted paper mill residuals (PMR) on soil properties, crop 
diseases, and crop productivity under field conditions. We have shown that PMR amendments increased total soil carbon after only 2 years, and that this resulted in a 5 to $50 \%$ increase in the soil's waterholding capacity (10). We conducted this study in Wisconsin's Central Sands, a region of intensive, irrigated vegetable production on sandy soils. We selected a 3year crop rotation consisting of potato (1998), snap bean (1999), and pickling cucumber (2000), which represents a typical rotation of processed vegetable crops in this region. Additionally, potato, snap bean, and cucumber are ideal crops for use in OM-mediated disease suppression experiments, because all are susceptible to an assortment of soilborne and foliar diseases that reduce yields. The objective of our research on vegetable crop diseases was to evaluate the effects of raw and composted PMR on soilborne and foliar diseases that occurred naturally during the first complete crop rotation cycle. Two seasons of potato disease data will be presented in a separate article.

\section{MATERIALS AND METHODS}

Two field trials were conducted at the University of Wisconsin Agricultural Research Station in Hancock. The predominant soil type is a Plainfield loamy sand (sandy, mixed, mesic, Typic Udipsamment; U.S. Soil Taxonomy). Both trials were constructed using a randomized complete block design, with amendment type/rate as the main treatment effect. Amendments were applied annually to the same plots.

Field trial one. Initiated in 1998, this trial consisted of five replications per treatment with treatment plots measuring 4.6 by $7.6 \mathrm{~m}$. Crops were grown in a 3 -year rotation consisting of potato (Solanum tuberosum, cv. Russet Burbank) in 1998, snap bean (Phaseolus vulgaris cv. True Blue; Harris Moran Seed Company, Modesto, CA) in 1999, and cucumber (Cucumis sativus, cv. SMR 18; Seminis Inc., Oxnard, CA) in 2000.

Amendments. Amendments (chemical characterization of amendments used in field experiments for each year are provided in Table 1) were applied 4 weeks prior to planting in 1999 and 2000. In 1998, amendments were applied 2 weeks prior to planting to accommodate the earlier planting date of potato. Fresh PMR, marketed to growers as ConsoGro, were obtained from Stora Enso North America (formerly Consolidated Papers Inc.), in Wisconsin Rapids. ConsoGro is a combination of the wood fiber fines, clay, calcium carbonate, and other mineral fillers collected from the primary wastewater settling process, as well as microbial biomass and partially stabilized paper mill effluent solids generated during the secondary aeration process.

PMR was applied at two rates each year. In 1998, PMR was applied at 22.4 and 44.8 dry t/ha to generate approximately 50 and $100 \%$ of the total potato nitrogen requirement of $224 \mathrm{~kg} / \mathrm{ha}$ (with the assumption that $25 \%$ of the total PMR nitrogen content would become available to the crop over the growing season; 27). In 1999 and 2000, PMR was applied at 22.4 and 33.6 dry $\mathrm{t} / \mathrm{ha}$, respectively, to supply the lower nitrogen requirements of snap bean and cucumber.

In 1998 and 1999, the PMR composted alone (PMRC) was derived from PMR produced by the Rhinelander Paper Company (Rhinelander, WI) that contained a 3:1 ratio $(\mathrm{vol} / \mathrm{vol})$ of primary and secondary process materials. These PMR were composted in outdoor windrows for approximately 5 months at the Oneida County landfill in Rhinelander, WI. In 2000, the PMRC was derived from ConsoGro composted at the University of Wisconsin, West Madison Agricultural Research Station using an open-air windrow system. The PMRC was formed into windrows $2 \mathrm{~m}$ tall by $3 \mathrm{~m}$ wide and turned every 2 to 4 weeks with a windrow turner for approximately 6 months. During the winter months (January to March), the windrows were covered with geotextile compost covers.

In 1998, a commercially available PMRbark compost (PMRBC) was obtained from Renewed Earth, Inc. (Kalamazoo, MI). This material was generated by windrow composting fresh PMR with hardwood bark for 3 months. In 1999 and 2000, compost made from an initial mixture of ConsoGro and bark (2:3, vol/vol) was composted at the West Madison site as described for PMRC.

PMRC and PMRBC were applied as carbon sources rather than nitrogen sources. In 1998, the composts were applied on a nearly equivalent dry weight basis to the high PMR rate (38.1 dry t/ha) and twice the high rate (78.4 dry t/ha). Composted amendments were reapplied to the same treatment plots at equivalent rates in April of 1999 and 2000. All amendments were applied to plots on a weight basis and spread manually. A small tractor with a rotovator was used to incorporate the amendments to a soil depth of $15 \mathrm{~cm}$. A fertilized, nonamended treatment was used as a control. This treatment was rotovated in the same manner as PMR-amended plots to avoid the confounding effects of tillage.

Crop management. In April 1999, prior to re-amendment, composite soil samples were taken from each plot $(0$ to $15 \mathrm{~cm})$ to determine soil fertility status. All plots were fertilized with $\mathrm{K}$ as $\mathrm{KCl}$ based on soil test recommendations for snap bean. None of the treatment plots required additional $\mathrm{P}$. To raise the $\mathrm{pH}$ of control plots to a level equivalent to the amended plots, 80/89 agricultural lime was applied at $4 \mathrm{t} / \mathrm{ha}$. Snap bean was seeded on 27 May 1999 at a rate of 39 seed $\mathrm{m}^{-1}$. All plots received $\mathrm{NH}_{4} \mathrm{NO}_{3}$ as a starter fertilizer $(22 \mathrm{~kg} / \mathrm{ha})$ and as a banded application (33 kg/ha) at both the third and sixth trifoliolate growth stages. Beans were hand harvested from two 3-m sections of row when $50 \%$ of the beans were sieve size 5 (11 $\mathrm{mm}$ in diameter).

Cucumber was seeded 22 June 2000. Two seeds were sown per hole $(0.172 \mathrm{~cm}$ apart in row and $0.92 \mathrm{~m}$ between rows) and thinned following emergence to 41 plants per 7.62-m row. All plots were fertilized with $\mathrm{K}$ as $\mathrm{KCl}$ based on soil test recommendations in mid-June prior to crop

Table 1. Chemical characteristics of amendments applied in 1998, 1999, and 2000

\begin{tabular}{|c|c|c|c|c|c|c|c|c|c|}
\hline \multirow[b]{3}{*}{ Amendment $^{\mathrm{z}}$} & \multicolumn{9}{|c|}{ Chemical characteristic } \\
\hline & \multicolumn{4}{|c|}{$\left(\mathrm{g} \mathrm{kg}^{-1}\right)$} & \multicolumn{2}{|c|}{$\left(\mathrm{mg} \mathrm{kg}^{-1}\right)$} & \multirow{2}{*}{$\frac{\left(\mathrm{S} \mathrm{m}^{-1}\right)}{\text { Salts }}$} & \multirow[b]{2}{*}{ pH } & \multirow[b]{2}{*}{$\mathbf{C} / \mathbf{N}$} \\
\hline & Solids & Ash & Total N & Total C & $\mathrm{NH}_{4}-\mathrm{N}$ & $\mathbf{N O}_{3}-\mathbf{N}$ & & & \\
\hline \multicolumn{10}{|l|}{1998} \\
\hline PMR & 199.0 & 345.3 & 11.2 & 263.6 & 256.0 & 2.3 & 0.8 & 7.0 & 23.5 \\
\hline PMRC & 312.5 & 452.7 & 15.6 & 268.3 & 41.3 & 32.7 & 1.6 & 7.4 & 17.2 \\
\hline PMRBC & 344.9 & 197.4 & 17.1 & 340.2 & 7.5 & 4.0 & 0.4 & 7.9 & 19.9 \\
\hline \multicolumn{10}{|l|}{1999} \\
\hline PMR & 227.0 & 366.1 & 15.5 & 296.9 & 66.4 & 4.0 & 0.29 & 7.0 & 19.2 \\
\hline PMRC & 414.0 & 676.4 & 12.3 & 144.8 & 76.5 & 0.3 & 0.16 & 7.9 & 11.7 \\
\hline PMRBC & 370.2 & 356.8 & 13.8 & 322.4 & 16.6 & 4.1 & 0.15 & 8.0 & 23.4 \\
\hline \multicolumn{10}{|l|}{2000} \\
\hline PMR & 911.5 & 390.0 & 16.8 & 296.0 & 74.5 & 1.9 & 0.08 & 7.5 & 17.6 \\
\hline PMRC & 916.0 & 458.6 & 19.5 & 259.5 & 139.5 & 26.6 & 0.12 & 7.4 & 13.3 \\
\hline PMRBC & 898.0 & 429.3 & 16.4 & 277.9 & 18.2 & 64.4 & 0.05 & 7.5 & 16.9 \\
\hline
\end{tabular}

${ }^{\mathrm{z}} \mathrm{PMR}=$ paper mill residuals, raw; PMRC $=$ composted PMR; PMRBC $=$ PMR composted with bark. 
planting. Cucumber plants in all treatments were side dressed at the third-leaf stage with $\mathrm{NH}_{4} \mathrm{NO}_{3}$ at $18 \mathrm{~kg} / \mathrm{ha}$ with the exception of the high rate of PMR, which received only $9 \mathrm{~kg} / \mathrm{ha}$. At vine tip-over, all plots were side dressed with $\mathrm{NH}_{4} \mathrm{NO}_{3}$ at the same rates applied at the trifoliate stage. In addition, all treatments received a polymer-coated urea (PolyonAg; $42 \%$ total nitrogen; Pursell Technologies, Inc., Sylacauga, AL) at $295 \mathrm{~kg} / \mathrm{ha}$.

For both crops, insect pests were managed according to recommendations by staff of the University of Wisconsin IPM Extension Program and Hancock Agricultural Research Station. Weeds were controlled by hoeing and surface rototilling throughout the growing season for snap bean or until the canopy closed for cucumber.

Field trial two. A second field trial was established in 1999 adjacent to field trial one, consisting of four replications per treatment with treatment plots measuring 3.7 by $7.6 \mathrm{~m}$. The objective of this trial was to investigate PMR and PMR compost effects on the severity of snap bean common root rot. These plots had no previous history of snap bean production; therefore, the crop was planted to bean in both 1999 and 2000 to create favorable conditions for a common root rot epidemic using the practices described for field trial one.

Amendments were applied 4 weeks prior to planting in 1999 and 2000. The amendments included (i) PMR, applied in both years at 11, 22, and 33 dry t/ha; (ii) PMRC, applied in both years at 38 and 76 dry t/ha; (iii) PMRBC: applied in both years at 38 and 76 dry t/ha; (iv) PMRBC (1), applied at 38 and 76 dry t/ha only in 1999; and (v) a nonamended control. Crops were managed for weed and insect pests as described for field trial one.

Disease assessment. All crops in field trials one and two were monitored and evaluated for natural disease occurrence. Disease diagnoses were confirmed by the University of Wisconsin Plant Disease Clinic using standard microbiological techniques to identify the probable pathogen or pathogens from symptomatic plant tissues.

All naturally occurring diseases were evaluated in both field trials each year. Pythium blight of snap bean (causal agent Pythium ultimum) was observed in field trial one following seedling emergence in 1999, but was not observed in field trial two. There was very low incidence and severity of foliar brown spot of snap bean (causal agent Pseudomonas syringae pv. syringae) in field trial two in both 1999 and 2000. However, an epidemic of foliar brown spot of snap bean occurred in field trial one in 1999. Incidence and severity of common root of snap bean (causal agents Aphanomyces euteiches and Pythium ultimum) were very low in both field trials in 1999. An epidemic of common root rot of snap bean occurred in field trial two in 2000. An epidemic of angular leaf spot (causal agent Pseudomonas syringae pv. lachrymans) of cucumber occurred in field trial one in 2000. Cucumber bioassays were performed in situ (in field) in both 1999 and 2000 and a snap bean foliar anthracnose bioassay was conducted in the greenhouse in fall 2001.

Diseases of field-grown snap bean. $P y$ thium blight of snap bean. The proportion of plants with necrotic lesions on the foliage in two 6.1-m sections of row was counted on 14 June 1999 (18 days after planting).

Brown spot of snap bean. Disease severity was rated using the Horsfall-Barratt scale (14) to assess the proportion of bean canopy with symptoms in three 1.8 -m-row sections per plot prior to harvest, where 0 $=$ no disease, $1=0$ to $3 \%, 2=3$ to $6 \%, 3=$ 6 to $12 \%, 4=12$ to $25 \%, 5=25$ to $50 \%, 6$ $=50$ to $75 \%, 7=75$ to $88 \%, 8=88$ to $94 \%, 9=94$ to $97 \%, 10=97$ to $100 \%$, and $11=100 \%$ of foliage affected. The disease severity indices (DSIs) for the three sections of row were averaged to generate a single DSI for each plot. Pods were harvested as described previously under "crop management" and rated as proportion of total pods with disease symptoms.

Common root rot of snap bean. All plants from two 3-m sections of row were dug at harvest from each plot in field trial two in 1999. Thirty of those plants were arbitrarily selected and evaluated for disease severity as described by Kobriger et al. (15), where $0=$ healthy; $1=$ slightly discolored roots, hypocotyl firm; 2 = moderately discolored roots, hypocotyl collapses under pressure; 3 = darkly discolored roots, hypocotyl collapses easily under pressure; $4=$ dead or dying plant.

Diseases of field-grown pickling cucumber. Angular leaf spot of cucumber (causal agent, Pseudomonas syringae $p v$. lachrymans). The total number of cucumber plants within two designated adjacent rows in each plot was counted and the number of plants exhibiting angular leaf spot symptoms was recorded 27 days after planting on 19 July, at 35 days on 27 July, and again at 46 days on 7 August. Plants were symptomatic if at least one leaf contained at least one yellow lesion typical of angular leaf spot. Incidence was expressed as the proportion of symptomatic plants per plot.

In-situ disease bioassays. Cucumber damping-off (causal agent, Pythium spp.). In situ field bioassays were conducted 1 month after amendments were applied and immediately after planting snap bean in 1999, and 1 month after amendments were applied and 2 weeks before planting cucumber in 2000. Four seed of cucumber "Straight Eight" were sown in treatment soils placed into PVC tubes, $7.6 \mathrm{~cm}$ in diameter by $15 \mathrm{~cm}$ long, inserted into field plots (two tubes per plot). Tubes were wa- tered to field capacity daily to create conditions conducive to seedling damping-off. Disease symptoms were rated 10 days after planting on a 0 -to- 4 scale, where $1=$ symptomless; 2 = emerged but wilted, chlorotic, or with visible lesions on the hypocotyl; 3 = post-emergence damping-off; and $4=$ pre-emergence damping-off. Seed were excavated from the soil to determine whether they were diseased or were healthy but did not germinate. A mean DSI was calculated for each tube. The DSIs for the two bioassays in each plot were averaged to generate a mean DSI for each plot.

Greenhouse bioassays. Anthracnose of snap bean (causal agent Colletotrichum lindemuthianum). Soil (0 to $15 \mathrm{~cm}$ in depth) was sampled from each treatment in field trial one (one composite per treatment) and placed into five $15.2-\mathrm{cm}$ clay pots in October 1999. Six seed of snap bean "True Blue" were planted into each pot. A natural infestation of bean anthracnose (pathogen isolated) occurred 4 weeks after planting. Symptoms were assessed using a 0 -to- 4 scale, where $0=$ no disease, $1=0$ to $25 \%, 2=26$ to $50 \%, 3=51$ to $75 \%$, and $4=76$ to $100 \%$ of foliage affected.

Statistical analyses. Subsamples taken in disease ratings were averaged per plot prior to analysis of variance. Treatment effects on most diseases were analyzed using analysis of variance (SigmaStat, SPSS, Inc., Chicago, IL) or the PROC GLM and PROC MIXED procedures of SAS (SAS Institute, Cary, NC). Fisher's protected least significant difference (LSD) test at $P \leq 0.05$ was used to separate treatment means.

In the case of angular leaf spot of cucumber, arcsine square root transformations of the incidence data were performed prior to analysis. Data were analyzed as a "repeated measures" design with field plot as the main experimental unit and time as the repeated measure within plot. Analysis of variance was performed with the SAS (SAS Institute) procedure PROC MIXED using the REPEATED statement. The Greenhouse Geisser correction for autocorrelation (SAS Institute) was applied to degrees of freedom for $F$ tests involving time and least square differences for comparing treatments at the same time. Treatment means at any single date were compared using Fisher's protected LSD at $P \leq$ 0.05 .

\section{RESULTS}

Field trial one. In 1999, all amendments, regardless of type or rate, increased snap bean emergence by an average of $14.7 \%$ compared with the nonamended control (Table 2). There were no significant differences in emergence among amended treatments. Similarly, all amendments reduced the incidence of Pythium blight by approximately $87 \%$ compared with the control (Table 2). There were no 
significant differences in the incidence of Pythium blight among amended treatments. The incidence and severity of common root rot of snap bean were too low in 1999 to evaluate. This is not surprising, because this field had no history of snap bean production for the previous 10 years.

All amendments suppressed symptoms of foliar brown spot of bean relative to the control, and there were differences among amendments $(P<0.0001)$. The low rate of PMR was significantly more suppressive to foliar brown spot than the high rate of PMR. Both application rates of PMRC significantly reduced the incidence of brown spot symptoms on bean pods compared with other treatments (Table 2). Only PMR increased yield of snap bean (Table 2).

Symptoms of angular leaf spot (ALS) of cucumber occurred in all experimental plots on 17 July 2000. On that date, the incidence of ALS in the low rate of PMRC was $50 \%$ lower $(P=0.06)$ than incidence the low rate of PMRC and the high rate of

in the nonamended control (Table 3). On 26 July, ALS incidence was significantly lower in the high and low rates of PMRC compared with the control. On 7 August, ALS incidence was significantly lower in the high and low rates of PMRC and the low rate of PMRBC compared with the control (Table 3). Regardless of application rate, incidence of ALS in PMRC treatments did not significantly change from 17 July to 7 August $(P=0.82$, PMRC H; $P=$ 0.76 , PMRC L). The incidence of ALS also remained unchanged in the nonamended control during the course of the experiment ( $P=0.12$, 17 July to 7 August).

Neither rate of PMRBC influenced the incidence of ALS during the course of the experiment compared with the nonamended control $(P=0.19)$, except at 46 days after planting (7 August), when the low rate of PMRBC had half as many symptomatic plants $(P=0.006)$ as the nonamended control plots. Plots amended with PMR did not have a significant effect on ALS compared with the nonamended

Table 2. Effect of organic amendments on emergence, field disease incidence and severity, and yield of snap bean in field trial one $(1999)^{\mathrm{w}}$

\begin{tabular}{lccccc}
\hline Treatment $^{\mathbf{x}}$ & Emergence $^{\mathbf{y}}$ & $\begin{array}{c}\text { Pythium } \\
\text { blight (\%) }\end{array}$ & $\begin{array}{c}\text { Foliar severity } \\
\text { brown spot }^{\mathbf{z}}\end{array}$ & $\begin{array}{c}\text { Pod incidence } \\
\text { brown spot (\%) }^{\text {(\%) }}\end{array}$ & Yield (t/ha) \\
\hline PMR L & $37.3 \mathrm{~b}$ & $3.0 \mathrm{~b}$ & $2.3 \mathrm{c}$ & $22.9 \mathrm{~b}$ & $8.8 \mathrm{c}$ \\
PMR H & $38.4 \mathrm{~b}$ & $1.7 \mathrm{~b}$ & $3.4 \mathrm{~b}$ & $34.3 \mathrm{a}$ & $9.9 \mathrm{ab}$ \\
PMRC L & $36.2 \mathrm{a} *$ & $1.5 \mathrm{~b}$ & $1.5 \mathrm{~d}$ & $12.1 \mathrm{c}$ & $10.2 \mathrm{a}$ \\
PMRC H & $39.2 \mathrm{~b}$ & $1.7 \mathrm{~b}$ & $1.1 \mathrm{~d}$ & $7.6 \mathrm{c}$ & $8.6 \mathrm{c}$ \\
PMRBC L & $38.8 \mathrm{~b}$ & $1.9 \mathrm{~b}$ & $2.4 \mathrm{c}$ & $25.3 \mathrm{ab}$ & $9.4 \mathrm{abc}$ \\
PMRBC H & $38.0 \mathrm{~b}$ & $1.7 \mathrm{~b}$ & $2.5 \mathrm{c}$ & $23.3 \mathrm{~b}$ & $8.9 \mathrm{bc}$ \\
Control & $33.1 \mathrm{a}$ & $15.0 \mathrm{a}$ & $3.9 \mathrm{a}$ & $24.7 \mathrm{ab}$ & $8.4 \mathrm{c}$ \\
LSD (0.05) & 3.7 & 6.6 & 0.5 & 10.0 & 1.0 \\
\hline
\end{tabular}

${ }^{\text {w}}$ Means within a column ( $n=$ five replicates $)$ followed by the same letter are not significantly different according to Fisher's protected least significant difference (LSD; $P \leq 0.05$ ); $*=$ significant at $P$ $\leq 0.10$.

${ }^{\mathrm{x}}$ Treatments were paper mill residuals (PMR), raw; PMR composted without (PMRC) and with bark (PMRBC); and a nonamended soil control. Composted amendments were applied to soil at rates of $38.1(\mathrm{~L})$ and $78.4(\mathrm{H})$ dry t/ha and raw amendment was added at $22.4(\mathrm{~L})$ and $33.6(\mathrm{H})$ dry t/ha.

${ }^{\mathrm{y}}$ Number of plants in $1.22 \mathrm{~m}$.

${ }^{\mathrm{z}}$ Rated as the proportion of canopy with symptoms (three subsamples/replicate) using the HorsfallBarratt scale, where $0=$ no disease, $1=0$ to $3 \%, 2=3$ to $6 \%, 3=6$ to $12 \%, 4=12$ to $25 \%, 5=25$ to $50 \%, 6=50$ to $75 \%, 7=75$ to $88 \%, 8=88$ to $94 \%, 9=94-97 \%, 10=97$ to $100 \%$, and $11=$ $100 \%$ of foliage affected.

Table 3. Effect of organic amendments on the incidence of angular leaf spot of cucumber in field trial one (2000)

\begin{tabular}{lcccc}
\hline & & \multicolumn{3}{c}{ Symptomatic plants (\%) $^{\mathbf{y}}$} \\
\cline { 3 - 5 } Treatment $^{\mathbf{z}}$ & No. of plants & $\mathbf{1 7}$ July & 26 July & 7 August \\
\hline PMR L & $77 \mathrm{a}$ & $23 \mathrm{a}$ & $32 \mathrm{a}$ & $28 \mathrm{a}$ \\
PMR H & $79 \mathrm{a}$ & $18 \mathrm{a}$ & $30 \mathrm{a}$ & $30 \mathrm{a}$ \\
PMRC L & $81 \mathrm{a}$ & $14 \mathrm{a}$ & $20 \mathrm{bc}$ & $16 \mathrm{~b}$ \\
PMRC H & $78 \mathrm{a}$ & $15 \mathrm{a}$ & $14 \mathrm{c}$ & $8 \mathrm{c}$ \\
PMRBC L & $80 \mathrm{a}$ & $17 \mathrm{a}$ & $28 \mathrm{ab}$ & $17 \mathrm{~b}$ \\
PMRBC H & $80 \mathrm{a}$ & $25 \mathrm{a}$ & $29 \mathrm{ab}$ & $27 \mathrm{a}$ \\
Control & $80 \mathrm{a}$ & $28 \mathrm{a}$ & $36 \mathrm{a}$ & $36 \mathrm{a}$ \\
LSD $(0.05)$ & NS & NS & 9.4 & 8.2 \\
\hline
\end{tabular}

y The percentage of cucumber plants exhibiting symptoms of angular leaf spot within two adjacent $1.22-\mathrm{m}$ rows per plot was calculated based on total number of plants, provided in the first column. Column values represent means of $n=$ five replicates. Means within a column followed by the same letter are not significantly different according to Fishers protected least significant difference $(\mathrm{LSD} ; P \leq 0.05)$. NS $=$ not significant.

${ }^{\mathrm{z}}$ Treatments were paper mill residuals (PMR), raw; PMR composted without (PMRC) and with bark (PMRBC); and a nonamended soil control. Composted amendments were applied to soil at rates of $38.1(\mathrm{~L})$ and $78.4(\mathrm{H})$ dry t/ha and raw amendment was added at $22.4(\mathrm{~L})$ and $33.6(\mathrm{H})$ dry $\mathrm{t} / \mathrm{ha}$. control during the course of the experiment.

Field trial two. There was no previous history of snap bean production in field trial two and, consequently, the incidence and severity of common root rot was low in 1999. Snap bean was planted for a second year in field trial two in 2000 and, subsequently, the incidence and severity of common root rot was higher in the 2000 bean crop (Fig. 1). All amendments reduced the severity of common root rot of snap bean compared with the nonamended control, regardless of PMR type or rate (Fig. 1). In most cases, the amendments applied at high rates were more suppressive than the low rates, except for PMRBC plots that received amendments both years. The low and high rates of PMR reduced symptoms significantly more than the very low rate of PMR. There was no significant difference in the severity of common root rot in the very low rate of PMR, the low rate of PMRC, and the low rate of PMRBC (1). Disease severity was significantly higher in the very low rate of PMR, low rate of PMRC, and the low rate of PMRBC compared with the other amended treatments, but still significantly lower than the nonamended control.

In situ and greenhouse bioassays. There were significant treatment effects observed in the in situ cucumber bioassays in $1999(P=0.0005)$ and $2000(P=0.001$; Table 4). In 1999, all of the amendments reduced symptoms of damping-off in the in situ cucumber bioassays, but there were no significant differences among amendment type or rate. In 2000, all amendments significantly reduced severity of damping-off in cucumber relative to the nonamended control, except for the low rate of PMRC. There were some significant differences among amendment types and rates in 2000. The high rates of PMR and PMRC significantly reduced severity of damping-off compared with the low rates of these amendments, while rate did not affect severity in PMRBC treatments. The high rate of PMR was significantly more suppressive to damping-off than all other treatments except the high rate of PMRC (Table 4).

In a snap bean greenhouse bioassay, only the high rate of PMRC significantly $(P=$ 0.0001 ) reduced the severity of anthracnose caused by $C$. lindemuthianum compared with the nonamended control. The low rate of PMR increased the severity of symptoms compared with the nonamended control.

\section{DISCUSSION}

In general, all amendments in this study increased the emergence of snap bean (Table 2) and suppressed Pythium blight of snap bean (Table 2) and damping-off of cucumber (Table 4). The suppression of Pythium damping-off has been reported for a variety of organic materials in both con- 
tainer mixes (13) and field soils $(17,19)$. To our knowledge, the suppression of foliar Pythium blight of snap bean has not been reported previously. In addition, all amendments suppressed common root rot of snap bean (causal agents Aphanomyces euteiches and Pythium spp.). Organic waste- and plant residue-mediated suppression of diseases caused by Aphanomyces spp. also has been reported previously $(21,22,26,34)$. Overall, there was little difference in suppressiveness of diseases caused by pathogenic Oomycetes among types of organic matter (fresh or composted).

Soil amended with PMRBC sustained suppression of common root rot in the second year without reapplying the amendments (Fig. 1). Barks have been shown to suppress plant diseases caused by Pythium and Phytophthora spp. for up to 2 years during decomposition under greenhouse conditions (12). Therefore, it is not surprising that PMRBC was suppressive 1 year after amendment application.

There are currently few viable control strategies for common root rot and Pythium blight of snap bean. Chemical fumigation is not an economically practical management strategy for these diseases. Growers typically fumigate before planting potato, and planting snap bean the year following potato can be an effective control strategy for common root rot. Some vegetable farms in Wisconsin's Central Sands receive PMR at 20 dry t/ha (similar to the low rate of PMR), and this application rate suppressed common root rot and Pythium blight of snap bean (Fig. 1; Table 2). Application of PMR at similar rates at least 1 month before the planting of snap bean should be further evaluated for the management of common root rot and Pythium blight.

Overall, PMRC was the most suppressive amendment to foliar diseases of bean and cucumber (Tables 2, 3, and 4), although all amendments suppressed foliar brown spot of bean to some extent (Table 2). In contrast to OM-mediated suppression of diseases caused by Pythium spp., amendment type was a strong determinant of foliar disease suppression. Similarly, other researchers have documented that, although most organic materials suppress Pythium damping-off and root rot, fewer suppress bacterial leaf spot of radish (16). Anthracnose of cucumber was suppressed in a compost-amended container mix (36), while there have been no previous reports, to our knowledge, of OM- or plant growth promoting rhizobacteria-mediated foliar brown spot suppression.

There is some evidence that composted PMR amendments may reduce diseases by inducing plant defenses. Using soil collected from field trial one, Vallad et al. (31) found that Arabidopsis thaliana and tomato grown in PMRC and PMRBC suppressed foliar symptoms of bacterial speck caused by Pseudomonas syringae pv. tomato, and exhibited molecular characteristics indicative of induced resistance. Severity of Fusarium crown and root rot (causal agent, Fusarium oxysporum f. sp. radicislycopersici) was lower in tomato plants grown in a container mix containing composted PMR compared with an unamended control (28). Intriguingly, this PMRmediated disease suppression was associated with the induction of various cyto- logical responses that occurred at attempted penetration sites by the fungal pathogen, and only in the presence of the pathogen, suggestive of induced resistance.

In summary, soilborne diseases caused by Pythium spp. and A. euteiches were suppressed by raw and composted PMR amended to sandy field soils. In contrast, only the PMRC was consistently suppressive to foliar brown spot and anthracnose of snap bean and ALS of cucumber. Simi-

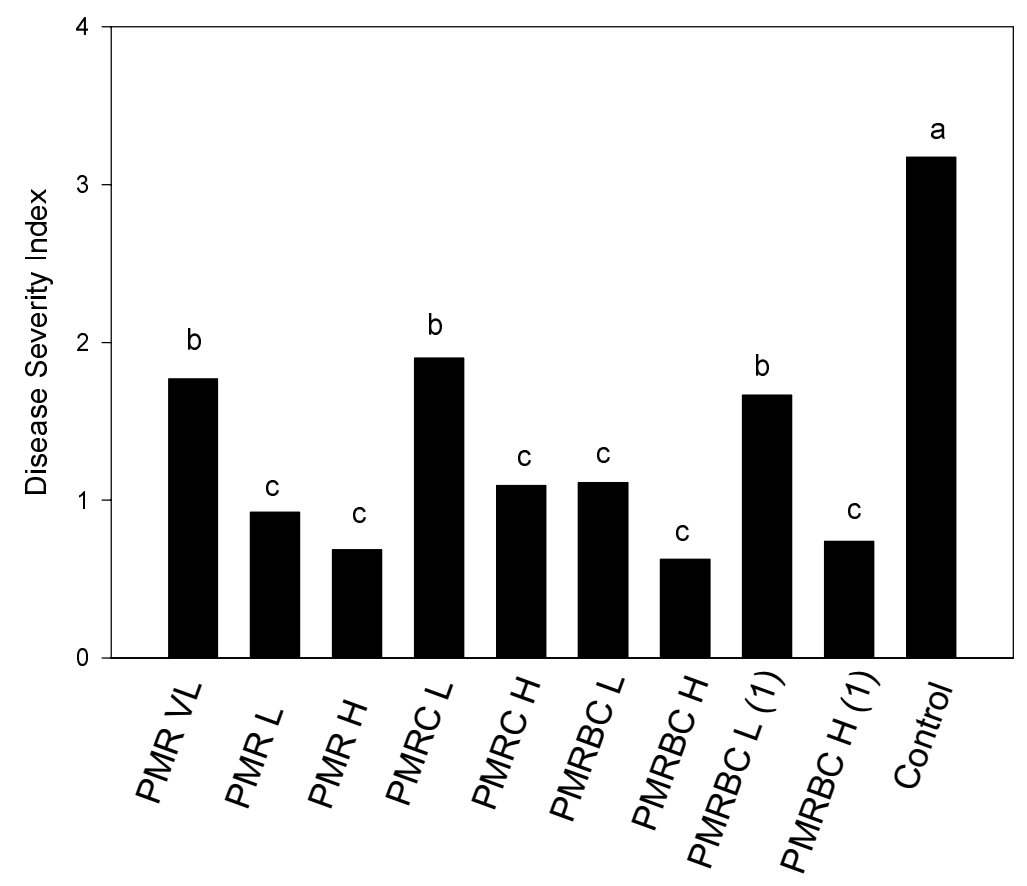

Fig. 1. Effect of organic amendment on the severity of common root rot of field-grown snap bean (2000). Treatments included raw paper mill residuals (PMR) applied to soil in both years at the rates of $11(\mathrm{VL}), 22(\mathrm{~L})$, and $33(\mathrm{H})$ dry t/ha; PMR composted without a bulking agent (PMRC) or composted with bark (PMRBC) at the rates of $38(\mathrm{~L})$ and $76(\mathrm{H})$ dry t/ha applied both years; and PMRBC (1) which was the same as PMRBC treatments but was only amended in 1999. Disease severity was rated using a 5 -point scale, where $0=$ healthy and $5=$ dead or dying plant. Bars topped by the same letters are not significantly different according to Fisher's protected least significant difference $=0.53(P \leq 0.05)$.

Table 4. The effect of organic amendments on Pythium damping-off of cucumber in in situ bioassays and anthracnose of snap bean in a greenhouse bioassayw

\begin{tabular}{lccc}
\hline & \multicolumn{2}{c}{ Cucumber damping-off $^{\mathbf{x}}$} & \\
\cline { 2 - 3 } Treatment $^{\mathbf{y}}$ & $\mathbf{1 9 9 9}$ & $\mathbf{2 0 0 0}$ & \\
\hline PMR L & $1.88 \mathrm{~b}$ & $2.30 \mathrm{~b}$ & $2.7 \mathrm{a}(18)$ \\
PMR H & $1.43 \mathrm{~b}$ & $1.33 \mathrm{~d}$ & $2.2 \mathrm{~b}(24)$ \\
PMRC L & $1.55 \mathrm{~b}$ & $2.43 \mathrm{ab}$ & $1.5 \mathrm{c}(15)$ \\
PMRC H & $1.83 \mathrm{~b}$ & $1.65 \mathrm{~cd}$ & $0.8 \mathrm{~d}(24)$ \\
PMRBC L & $1.73 \mathrm{~b}$ & $2.13 \mathrm{bc}$ & $2.2 \mathrm{~b}(22)$ \\
PMRBC H & $1.73 \mathrm{~b}$ & $2.18 \mathrm{bc}$ & $2.0 \mathrm{~b}(23)$ \\
Control & $3.08 \mathrm{a}$ & $2.98 \mathrm{a}$ & $1.9 \mathrm{bc}(22)$ \\
LSD $(0.05)$ & 0.68 & 0.61 & 0.5 \\
\hline
\end{tabular}

${ }^{\text {w}}$ Means within a column ( $n=$ five replicates) followed by the same letter are not significantly different according to Fisher's protected least significant difference (LSD; $P \leq 0.05$ ).

${ }^{x}$ Disease severity index based on a rating scale of $1=$ symptomless; $2=$ emerged but wilted, chlorotic or with visible lesions on the hypocotyl; $3=$ post-emergence damping-off; and $4=$ preemergence damping-off.

${ }^{\mathrm{y}}$ Treatments were paper mill residuals (PMR), raw; paper mill residuals composted without (PMRC) and with bark (PMRBC); and a nonamended soil control. Composted amendments were applied to soil at rates of $38.1(\mathrm{~L})$ and $78.4(\mathrm{H})$ dry t/ha and raw amendment was added at $22.4(\mathrm{~L})$ and 33.6 (H) dry t/ha.

${ }^{\mathrm{z}}$ Disease severity based on a five-point scale, where $0=$ no disease, $1=0$ to $25 \%, 2=25$ to $50 \%, 3$ $=50$ to $75 \%$, and $4=75$ to $100 \%$ of foliage with symptoms. Values in parenthesis represent total number of plants from a possible 24 ( 4 replicates $\times 6$ samples) in an unbalanced data set. 
lar trends in Pythium spp. and foliar disease suppression have been reported in studies using compost-amended container mixes (16,36,37). PMR amendments should be investigated further as control measures for Pythium blight and common root rot of snap bean in sandy agricultural soils. Soil and substrate properties related to OM-mediated root and foliar disease suppression also should be investigated further.

\section{ACKNOWLEDGMENTS}

We thank B. Rand, L. Crubaugh, and J. Staub for help with field disease assessments; B. Foley, J. Ravet, C. Newman, A. Rissman, and K. Niemann for their assistance with field work, data collection, and data analysis; A. Gilbert and B. Koslowski of Stora Enso, Inc. for collaboration; and the crews of the University of Wisconsin Hancock and West Madison Agricultural Research stations.

\section{LITERATURE CITED}

1. Abbasi, P. A., Al-Dahmani, J., Sahin, F., Hoitink, H. A. J., and Miller, S. A. 2002. Effect of compost amendments on disease severity and yield of tomato in conventional and organic production systems. Plant Dis. 86:156-161.

2. Brady, N. C., and Weil, R. R. 2000. The Nature and Properties of Soils. Prentice Hall, Upper Saddle River, NJ.

3. Broadbent, P., and Baker, K. F. 1974. Behaviour of Phytophthora cinnamomi in soil suppressive and conducive to root rot. Aust. J. Agric. Res. 25:121-37.

4. Buysens, S., Huengens, K., and Poppe, J. 1996. Involvement of pyochelin and pyoverdin in suppression of Pythium-induced damping-off of tomato by Pseudomonas aeruginosa 7NSK2. Appl. Environ. Microbiol. 62:865-871.

5. Chen, W., Hoitink, H. A. J., and Schmitthenner, A. F. 1987. Factors affecting suppression of Pythium damping-off in container media amended with composts. Phytopathology 77:755-760.

6. Chet, I., 1987. Trichoderma-Application, mode of action, and potential as a biocontrol agent of soilborne plant pathogenic fungi. In: Innovative Approaches to Plant Disease Control. I. Chet, ed. Wiley, New York.

7. Cook, R. J., and Baker, K. F. 1983. The Nature and Practice of Biological Control of Plant Pathogens. The American Phytopathological Society. St. Paul, MN

8. Drinkwater, L. E., Letourneau, D. K., Workneh, F., van Bruggen, A. H., and Shennan, C. 1995. Fundamental differences between conventional and organic tomato agroecosystems in California. Ecol. Appl. 5:1098-1112.

9. Elad, Y., and Chet, I. 1987. Possible role of competition for nutrients in biocontrol of Py- thium damping-off. Phytopathology 77:190195.

10. Foley, B. J., and Cooperband, L. R. 2002. Paper mill residuals and compost effects on soil physical properties in an irrigated vegetable rotation. J. Environ. Qual. 31:2086-2095.

11. Fravel, D. R. 1988. Role of antibiosis in the biological control of plant diseases. Annu. Rev. Phytopathol. 26:75-91.

12. Hoitink, H. A. J., and Boehm, M. J. 1999. Biocontrol within the context of soil microbial communities: a substrate-dependent phenomenon. Annu. Rev. Phytopathol. 37:427446.

13. Hoitink, H. A. J., Inbar, Y., and Boehm, M. J. 1991. Status of compost-amended potting mixes naturally suppressive to soilborne diseases of floricultural crops. Plant Dis. 75:869873.

14. Horsfall, J. G., and Barratt, R. W. 1945. An improved grading system for measuring plant disease. (Abstr.) Phytopathology 35:655.

15. Kobriger, K. M., Hagedorn, D. J., and Stevenson, W. R. 1998. Analysis of the snap bean root rot potential of WI fields. Univ. Wisc. Ext. Bull. A3242.

16. Krause, M. S., DeCeuster, T. J. J., Han, D. Y., Musselman, C. A., and Hoitink, H. A. J. 1998. Systemic acquired resistance induced by composts: a highly specific phenomenon. (Abstr.) Phytopathology 88:S49.

17. Lewis, J. A., Lumsden, R. D., Millner, P. D., and Keinath, A. P. 1992. Suppression of damping-off of peas and cotton in the field with composted sewage sludge. Crop Prot. 11:260-266.

18. Liu, L., Kloepper, J. W., and Tuzun, S. 1995. Induction of systemic resistance in cucumber against angular leaf spot by plant growth-promoting rhizobacteria. Phytopathology 85:843847.

19. Lourd, M., and Bouhot, D. 1987. Research on and characterization of Pythium suppressive soils in Brazilian Amazonia. Bull. OEPP 17:569-575.

20. Lumsden, R. D., Garcia-E, R., Lewis, J. A., and Frias-T, G. A. 1987. Suppression of damping-off caused by Pythium spp in soil from the indigenous Chinampa agricultural system. Soil Biol. Biochem. 19:501-508.

21. Lumsden, R. D., Lewis, J. A., and Millner, P. D. 1983. Effect of composted sewage sludge on several soil-borne pathogens and diseases. Phytopathology 73:1543-1548.

22. Lyda, S. D. 1958. The effect of crop residues on seedling diseases of sugar beets caused by Aphanomyces cochlioides. Masters thesis. Montana State University, Bozeman.

23. Malajczuk, N. 1983. Microbial antagonism to Phytophthora. Pages 197-218 in: Phytophthora: Its Biology, Taxonomy, Ecology and Pathology. D. C. Erwin, S. BartnickiGarcia, and P. H. Tsao, eds. American Pathological Society, St. Paul, MN

24. Meera, M. S., Shivanna, M. B. Kageyama, K., and Hyakumachi, M. 1995. Response of cu- cumber cultivars to induction of systemic resistance against anthracnose by plant growth promoting fungi. Eur. J. Plant Pathol. 101:421-430.

25. Nesbitt, H. J., Malajczuk, N., and Glenn, A. R. 1979. Effect of organic matter on the survival of Phytophthora cinnamomi Rands, cause of dieback disease in Eucalyptus. Soil Biol. Biochem. 11:133-136.

26. Papavizas, G. C., and Lewis, J. A. 1971. Effect of amendments and fungicides on Aphanomyces root rot of peas. Phytopathology 61:215-220.

27. Peters, J. B. 1998. Land application of Consolidated Papers Consogro sludge to agricultural land. Research Report, University of Wisconsin-Madison, Soil and Plant Analysis Lab, Madison.

28. Pharand, B., Carisse, O., and Benhamou, N. 2002. Cytological aspects of compost-mediated induced resistance against Fusarium crown and root rot in tomato. Phytopathology 92:424-438.

29. Stone, A. G., Traina, S. J., and Hoitink, H. A. J. 2001. Particulate organic matter composition and Pythium damping-off of cucumber. Soil Sci. Soc. Am. J. 65:761-770.

30. Trankner, A. 1992. Use of agricultural and municipal wastes to develop suppressiveness to plant pathogens. Pages 35-42 in: Biological Control of Plant Diseases. E. C. Tjamos, G. C. Papavizas, and R. J. Cook, eds. Plenum Press, New York.

31. Vallad, G. E., Stone, A. G., Goodman, R. M. and Cooperband, L. R. 2000. Assessment of foliar disease suppression generated by papermill sludge amendments. (Abstr.) Phytopathology 90:S79.

32. van Bruggen, A. H. C. 1995. Plant disease severity in high-input compared to reducedinput and organic farming systems. Plant Dis. 79:976-984.

33. Wei, G., Kloepper, J. W., and Tuzun, S. 1996. Induced systemic resistance to cucumber diseases and increased plant growth by plant growth-promoting rhizobacteria under field conditions. Phytopathology 81:1508-1512.

34. Williams-Woodward, J. L., Pfleger, F. L. Fritz-Vincent, A., and Allmaras, R. R. 1997. Green manures of oat, rape, and sweet corn for reducing common root rot in pea (Pisum sativum) caused by Aphanomyces euteiches. Plant Soil 188:43-48.

35. Zhang, W., 1997. Disease suppression and systemic acquired resistance induced in plants by compost-amended potting mixes, compost water extracts, and no-tillage soil. Ph.D. dissertation. Ohio State University, Columbus.

36. Zhang, W., Dick, W. A., and Hoitink, H. A. J. 1996. Compost-induced systemic acquired resistance in cucumber to Pythium root rot and anthracnose. Phytopathology 86:1066-1070.

37. Zhang, W., Han, D. Y., Dick, W. A., Davis, K. R., and Hoitink, H. A. J. 1998. Compost and compost water extract-induced systemic acquired resistance in cucumber and Arabidopsis. Phytopathology 88:450-455. 